\title{
Statyba
}

\section{THE DEMAND FOR EXERGY DURING THE LIFE CYCLE OF DWELLING HOUSES}

\section{Martinaitis}

To cite this article: V. Martinaitis (1999) THE DEMAND FOR EXERGY DURING THE LIFE CYCLE OF DWELLING HOUSES, Statyba, 5:1, 53-58, DOI: 10.1080/13921525.1999.10531433

To link to this article: https://doi.org/10.1080/13921525.1999.10531433

曲 Published online: 26 Jul 2012.

Submit your article to this journal 지

山 Article views: 75 


\title{
TIPINIŲ DAUGIABUČIŲ PASTATŲ GYVAVIMO CIKLO EKSERGIJOS POREIKIŲ IZVERTINIMAS
}

\author{
V. Martinaitis
}

\section{Irvadas}

Gyvenamojo fondo namų šildymo ir veddinimo šilumos poreikius per metus nulemia pastaty šiluminès charakteristikos ir klimato sąlygos. Karštam vandeniui, apšvietimui, buities technologinei ịrangai reikia beveik dar tiek pat energijos. Energija reikalinga ne tik pastatui naudoti, bet ir ji sukurti. Tai apima sudetingą ir daugialypi statybos technologijos procesą. Daugiausia šios energijos (apie 70\%) sunaudojama pagaminti medžiagoms ir gaminiams. Kita dalis tenka transportavimui, montavimui ir administravimui. Pastato sukūrimui ir naudojimui reikalingą energiją ar jos dalį tiekia aprūpinimo energija sistema (elektra bei šiluma), o kad ji veiktų, reikia pirminès energijos išteklių.

Gyvenamuju namų statybos klausimų ekonominiai ir kompleksiniai ekspertiniai kriterijai leidžia ivvertinti konkretaus objekto projektavimo dalykus ir retai nagrinèja dešimtmečio ribas peržengiančias problemas [1, 2]. Pastato naudojimo ciklas siekia keletą dešimtmečiu ar šimtmetị. Deja, ekonominiu prognoziy patikimumas tolesnei perspektyvai yra mažesnis už kokių nors fizinių dydžiu prognozes. Štai, aštuntojo dešimtmečio pradžioje mūsu dienoms prognozuotos energijos išteklių kainos (pagal naftos kainas) šiuo metu yra vos ne tris kartus mažesnès. Dalis tuometinių reikalavimų pastatams rèmési taip ir nepasitvirtinusiomis ekonominèmis prognozèmis.

Šio darbo tikslas - jivertinti pastato gyvavimo ciklo (sukūrimo, naudojimo, sunaikinimo) fizinèmis (energijos) vertemis išreikštus poreikius.

\section{Tyrimo metodika}

Lietuvoje bei kitose vidutinio ar šiaurinio klimato zonose pastatai laikytini intensyviai energiją naudojančia technine sistema $[3,4]$. Pastato gyvavimo ciklui, siekiančiam keletą dešimtmečių ar šimtmetị, analizuoti, optimizuoti, prognozuoti pagrįstai galima taikyti fiziniais kriterijais pagrịstą termodinamikos, kaip universalaus mokslo apie energijos virsmus, metodologiją. Techninèje termodinamikoje dèl būtinybès glaustai ir vaizdžiai pavaizduoti problemas, susijusias su energijos virsmais ịvairiausiuose techniniuose ịrenginiuose, šeštajame dešimtmetyje kaip savarankiška kryptis išsiskyre specialus skyrius, susijęs su eksergijos samprata. Kartu su sisteminio požiūrio ir ekonomikos elementais formavosi inžinerinis metodas, kuris buvo pavadintas ekserginiu $[5,6]$.

Eksergija charakterizuoja bet kokio tipo energija ne tik pagal jos kieki, bet ir pagal kokybę. Ji apibūdina energijos tinkamumą techniniam panaudojimui bet kokiomis sąlygomis. Taigi eksergija yra tam tikras universalus energetinių išteklių matas. Tokia techninèmis, ekonominemis ir ekologinèmis sąsajomis pagrịsta metodika leidžia sèkmingai spręsti techninio ir ekonominio optimizavimo, išlaidy kompleksinèms gamyboms paskirstymo, didelių, techniniams objektams priklausančių, klasių apibendrintų charakteristikų suradimo uždavinius ir kt.

Turime reikalą su didžiaja sistema, kurios struktūriniai komponentai - tai klimato, pirminès energijos ištekliu, aprüpinimo energija ir pastatu sistemos. Šios sudètingos struktūros sistemos nagrinẻjimas, atsižvelgiant $\mathfrak{i}$ ją formuojančius ryšius, jos sudètinių daliụ tarpusavio sąveiką, galimas remiantis sisteminio požiūrio, sistemy teorijos ir sisteminès analizès sampratomis. Pasirinktas tyrimo metodas paremtas sisteminiu požiūriu, kai sisteminès analizès raida realizuojama derinant tarpusavyje termodinamikos eksergini ir ekonomikos gyvavimo ciklo vertès požiūrius. Buvo pasiūlytas pastato gyvavimo ciklo termodinaminio ivertinimo modelis $[7,4]$. 
Pagal sudarytą ir formalizuotą pastato gyvavimo ciklo termodinaminį modelị ịvertinamos sudètingos organizacijos patalpu mikroklimato palaikymo sistemos eksergijos sąnaudos per pasirinktą jos gyvavimo ciklą, taip pat nustatytas tų sąnaudụ pasiskirstymas tarp sistemų, sistemų elementų ir per gyvavimo ciklą.

Energiją naudojančị sistemų analizei taikomą metodiką, tos analizes rezultatus dažnai lemia vertinimo kriteriju pasirinkimas. Akcentuojant fizinį, termodinaminị požiūrị pagrindiniu vertinimo kriterijumi pasirinkta viso modelio, jo sistemų, jụ elementų ar procesu juose sukūrimo ir veikimo per pastato gyvavimo ciklą lyginamosios eksergijos sąnaudos, kurios pakankamai tiksliai gali būti tapatinamos su pirmines energijos poreikiu.

Nustatant daugiabučio pastato gyvavimo ciklo eksergijos (pirminès energijos) poreikius remtasi autoriaus pasiūlytomis [7] formulèmis, iš kuriu formule eksergijai nustatyti atrodytụ taip:

$$
E_{\mathrm{PGC}}=\sum_{\nu}\left(\sum_{e} V E_{e}\right)_{i}+\sum_{p}\left(\sum_{e} \frac{\sum \tau_{i}}{\tau_{e}} P E_{e}\right)_{i},
$$

čia $E_{\mathrm{PGC}}$ - eksergijos vienkartiniu ir pasikartojančiu verčiu suma per pastato gyvavimo ciklą; $V E_{c}$ eksergijos vertè iš $v$ bendrojo vienkartinès vertès etapy skaičiaus; $P E_{c}-e$ elemento $i$ etape eksergijos verté iš $p$ bendrojo pasikartojančios vertès etapų skaičiaus; $\tau_{i}$ $i$ etapo trukmé; $\tau_{e}-$ elemento gyvavimo trukmè. Šios vertès skaičiuojamos energijos vienetais vienam pastato bendrojo naudingojo ploto kvadratiniam metrui, pvz., $\mathrm{MWh} / \mathrm{m}^{2}$.

\section{Daugiabučio pastato gyvavimo ciklo eksergijos (pirminès energijos) poreikiai}

Pastato gyvavimo ciklo pirminès energijos poreikiams ivertinti buvo pasirinkti du stambiaplokščị ir du mūrinių namų tipai, kurių nemaža pastatyta Lietuvoje. Penkiu aukštu namo tipinis projektas 120-017.2 stambiaplokščiam ir I-318-52 mūriniam namui. Devyniu aukštų namo tipinis projektas 120-026.2 stambiaplokščiam ir I-318-91 mūriniam namui. Reikètų atkreipti demesį, kad stambiaplokščị namu projektai parengti 1986 metais, o mūriniu - 1977 metais. Šiame darbe nèra detalesnio nagrinejamy projektu sprendimu aptarimo, tačiau 1 lentelèje pateikti lyginamieji instaliuotosios galios rodikliai rodo, kad šiems pastatams priimti techniniai sprendimai yra skirtingi.
1 lentelė. Daugiabučiu pastatų lyginamoji instaliuotoji galia šildymui ir karšto vandens ruošimui

Table 1. Installed specific heat capacity of heating and hot water needs for multi-storey dwelling houses

\begin{tabular}{|l|c|c|c|c|}
\hline \multirow{2}{*}{$\begin{array}{c}\text { Šilumą } \\
\text { naudojanti } \\
\text { sistema }\end{array}$} & \multicolumn{4}{|c|}{ Projektinè instaliuotoji galia, W/m ${ }^{2}$} \\
\cline { 2 - 5 } & $120-017.2$ & $120-026.2$ & $\mathrm{I}-318-52$ & $\mathrm{I}-318-91$ \\
\hline $\begin{array}{l}\text { Šildymas ir } \\
\text { vèdinimas }\end{array}$ & 57,9 & 77,0 & 84,9 & 104,1 \\
\hline $\begin{array}{l}\text { Karštas } \\
\text { vanduo }\end{array}$ & 98,4 & 82,8 & 79,5 & 70,4 \\
\hline Iš viso & 156,3 & 159,8 & 164,4 & 174,5 \\
\hline
\end{tabular}

Dèl reikalingų struktūrinių fizinių duomenu trükumo šio darbo eksergijos poreikiu nustatymo skaitiniuose pavyzdžiuose pastato, jo aprūpinimo šiluma sistemu gyvavimo ciklo etapai ir vyraujantys fiziniai srautai jungiami $\mathfrak{i}$ didesnes grupes skirtingai, nei jie buvo aptarti [7]. 2 lenteléje yra pateikiami susumuoti pirminés energijos poreikiu jivertinimų duomenys, atlikti remiantis [7] pristatytu fiziniu (termodinaminiu) pastato gyvavimo ciklo modeliu.

2 lentelè. Pirminès energijos poreikiai skirtingais daugiabučiu pastatų gyvavimo ciklo etapais

Table 2. Primary energy (aprox. eqv. exergy) demands at different stages of building life cycle for dwelling houses

\begin{tabular}{|l|l|l|l|l|l|}
\hline \multirow{2}{*}{$\begin{array}{c}\text { Žy- } \\
\text { meji- } \\
\text { mas }\end{array}$} & $\begin{array}{l}\text { Pastato } \\
\text { gyvavimo } \\
\text { ciklo etapai }\end{array}$ & \multicolumn{4}{|l|}{ Pirminè energija, MWh/m ${ }^{2}$} \\
\cline { 3 - 6 } & $\begin{array}{l}120- \\
017.2\end{array}$ & $\begin{array}{l}120- \\
026.2\end{array}$ & $\begin{array}{l}\text { I-318- } \\
52\end{array}$ & $\begin{array}{l}\text { I-318- } \\
91\end{array}$ \\
\hline M & $\begin{array}{l}\text { Medžiagu } \\
\text { gamyba }\end{array}$ & 2,44 & 2,83 & 4,11 & 7,53 \\
\hline S & Statyba & 1,97 & 1,53 & 2,24 & 4,06 \\
\hline E1 & $\begin{array}{l}\text { Sildymas ir } \\
\text { vedinimas }\end{array}$ & 13,35 & 17,76 & 19,60 & 24,01 \\
\hline E2 & $\begin{array}{l}\text { Karštas } \\
\text { vanduo }\end{array}$ & 8,12 & 8,27 & 9,88 & 9,21 \\
\hline E3 & Apšvietimas & 6,83 & 6,83 & 6,83 & 6,83 \\
\hline E4 & $\begin{array}{l}\text { Buitiné } \\
\text { technika }\end{array}$ & 3,75 & 3,56 & 3,62 & 3,57 \\
\hline E5 & $\begin{array}{l}\text { Einamieji } \\
\text { remontai }\end{array}$ & 3,39 & 3,36 & 4,89 & 8,92 \\
\hline R1 & Renovacija I & 2,21 & 2,18 & 3,18 & 5,80 \\
\hline R2 & Renovacija II & 2,21 & 2,18 & 3,18 & 5,80 \\
\hline G & Nugriovimas & 0,59 & 0,46 & 0,67 & 1,22 \\
\hline & $\begin{array}{l}\text { Iš viso per } \\
\text { PGC }\end{array}$ & 44,86 & 48,95 & 58,21 & 76,94 \\
\cline { 2 - 6 } & & & & \\
\hline
\end{tabular}


Medžiagu ir gaminiu gamyba statybai sudaro $M$ etapą. Statybos tiksly formavimas, planavimas, derinimas, tyrinejimas, projektavimas bei statyba sudaro $\mathrm{S}$ etapą. Pastaroji sąvoka "statyba" suprantama kaip šio proceso administravimas, darbo jèga, paslaugos, transportavimas, mechanizmų naudojimas, energijos, kuro naudojimas. Eksploatavimas ir einamasis remontas sudaro etapą E. Medžiagų ir gaminiu gamyba renovacijai, renovacijos tyrinejimas, projektavimas ir atlikimas sudaro etapą R. Pastato nugriovimas, atlieku ir sklypo regeneravimas, duomenų sisteminimas, nauju technologijų kūrimas sudaro etapą G. M, S ir G etapai pagal gaminio gyvavimo ciklo vertès principą sudaro pastato gyvavimo ciklo vadinamąsias vienkartines vertes, o eksploatacija ir einamasis remontas E pasikartojančias vertes. Einamajam remontui šiame modelyje priskiriamos priemonés, kurių atlikimo periodiškumas nesiekia 20 metų, ir jos įtraukiamos i eksploataciją. Renovacija $\mathrm{R}$ formaliai priskiriama prie vienkartinių verčių, tačiau ji turi ir pasikartojančiu verčių požymių. Jai priskiriami ir pastato posistemiu atnaujinimai, kuriy gyvavimo trukmè daugiau kaip perpus kartus trumpesné nei pastato gyvavimo ciklas, bet kurie nepriskiriami eksploatacijai. Toks priskyrimas grindžiamas dar ir tuo, kad renovacijos apimtys numatomos atskiru tiksly formavimo, projektavimo ir atlikimo etapu. Pastato gyvavimo cikle galima numatyti ne vieną renovaciją.

Toliau aptariamos ši vertinimu prielaidos, kiti komentarai.

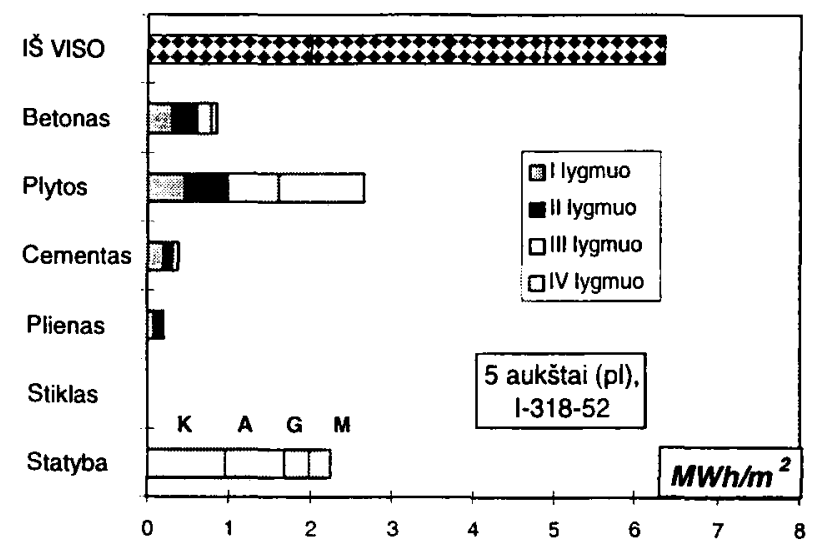

1 pav. Pirminès energijos poreikis 5 aukštų plytinio gyvenamojo namo medžiagu gamybai ir statybai

Fig 1. Primary energy demands of five-storey brick houses for material processing and construction

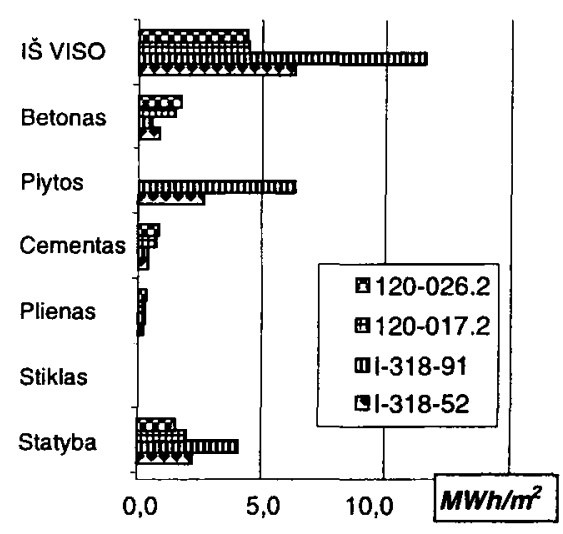

2 pav. Pirminès energijos poreikis gyvenamuju namy medžiagu gamybai ir statybai

Fig 2. Primary energy demands for material processing and construction of dwelling houses

\subsection{Tiesioginis pirminės energijos poreikių medžia- goms ir statybai ịvertinimas}

Pirminès energijos poreikiu medžiagoms ir statybai įvertinimų kai kurie duomenys parodyti 1 ir 2 paveiksluose. Tai atlikta tiesiogiai remiantis projektu duomenimis, atsižvelgiant $i \mathfrak{i}$ darbe [8] atliktus medžiagu gamybos pirminès energijos poreikiu įvertinimus. Techniniuose pastatu dokumentuose pateikiama informacija apie cemento, plieno, betono, plytu ir medžio poreikius. Papildomai buvo ivertintas stiklo poreikis. Pastaruju dvieju medžiagu energinès dalys šio tipo pastatuose siekia tik $0,3 \%$ ir toliau ne visuomet išskiriamos iš bendrujju rodiklių.

Atsižvelgiant $\mathfrak{i}[9]$ pateiktus santykinius duomenis, statybos procesui tenka $30 \%$ visos pastato sukūrimui reikalingos energijos (administravimas, darbo jèga, paslaugos $-11 \%$, transportavimas, mechanizmy naudojimas - $4 \%$, kuro sąnaudos - $15 \%$ ). Be to, įvertinant energijos sąnaudas statybai atsižvelgta, kad lyginamosios darbo laiko sąnaudos 120-017.2 pastatui yra 1,76 karto didesnés nei 120-026.2, o I-318-91 - net 2,7 karto didesnès nei 120-026.2.

Lyginamosios energijos sąnaudos pagrindinèms medžiagoms (cementui, betonui, plienui, plytoms, stiklui) ivertintos remiantis [8] gautais duomenimis ir ju lygiais. IV lygio sąnaudos 5 aukštu stambiaplokščiam pastatui yra $2,44 \mathrm{MWh} / \mathrm{m}^{2}$, o 9 aukštu pastatui $2,83 \mathrm{MWh} / \mathrm{m}^{2}$. Atitinkamai plytiniams pastatams $4,11 \mathrm{MWh} / \mathrm{m}^{2}$ ir $7,53 \mathrm{Mwh} / \mathrm{m}^{2}$.

Ivertinus ir statybos procesą šios reikšmès stambiaplokščiams namams tampa artimesnès viena kitai ir 
atitinkamai lygios $4,42 \mathrm{MWh} / \mathrm{m}^{2}$ ir $4,36 \mathrm{MWh} / \mathrm{m}^{2}$. JAV mokslininkų duomenimis [9], šis rodiklis daugiabučiams namams įvertinamas $2,45 \mathrm{MWh} / \mathrm{m}^{2}$. Skirtumui paaiškinti pakaktu paminèti tiek medžiagu gamybos, tiek statybos technologiju lygio skirtumus.

\subsection{Tiesioginis pirminès energijos pasikartojančiu poreikiu ịvertinimas}

Tolesniam nagrinejimui buvo pasirinkta 80 metu pastato gyvavimo ciklo trukmé, iš kuriu 2 metus pastatas negali būti naudojamas pagal paskirtị (statyba, renovacija, nugriovimas).

Gauti pasikartojančiu pirminès energijos poreikių (pastato eksploatacijai ir einamajam remontui) rezultatai šiems pastatams parodyti 3 ir 4 paveiksluose. Nagrinèjamụ pastatụ duomenys skaičiavimų komentaruose pateikiami šia tvarka: penkių bei devynių aukštų stambiaplokščiams ir penkių bei devynių aukšty plytiniams. Šilumos poreikiai šildymui per pastato gyvavimo ciklą Vilniuje, atsižvelgiant $i$ šildymo sezono ribų temperatūras $\left(18 / 8^{\circ} \mathrm{C}\right)[10]$ bei šilumos pritekejjimus, atitinkamai yra 9,28 bei $12,35 \mathrm{MWh} / \mathrm{m}^{2}$ stambiaplokščiams ir 13,63 bei $16,70 \mathrm{MWh} / \mathrm{m}^{2}$ mūriniams. Karštam vandeniui paruošti (pašildymui ir recirkuliacijai) tokiuose pastatuose reikia atitinkamai 6,46 bei $6,56 \mathrm{MWh} / \mathrm{m}^{2}$ ir 7,85 bei $7,30 \mathrm{MWh} / \mathrm{m}^{2}$. Iš viso šilumos, neatsižvelgiant i jos gamybos būdą ir termodinaminę vertę, šiems pastatams per jų gyvavimo ciklą reikia 15,74 bei 18,91 $\mathrm{MWh} / \mathrm{m}^{2}$ ir 21,48 bei $23,99 \mathrm{MWh} / \mathrm{m}^{2}$.

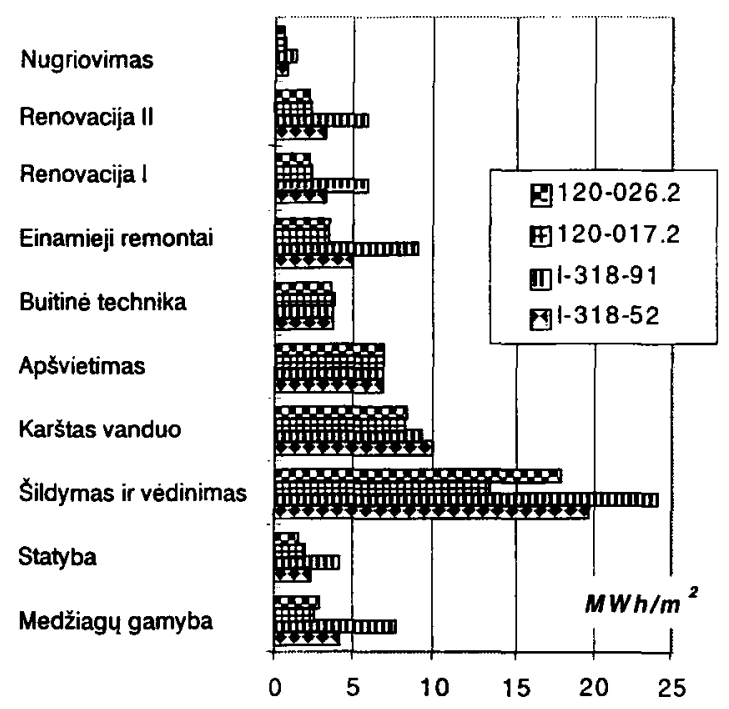

3 pav. Pirminès energijos pasikartojančios sąnaudos daugiabučiu pastatu gyvavimo cikle

Fig 3. Primary energy recurrent demands of building life cycle of dwelling houses
Nustatant šiai šilumai pagaminti tradicinèje aprūpinimo šiluma sistemoje su katilu sudeginamą organini kurą, ịvertinamas šilumos paskirstymo ir katilo veikimo sezoninis efektyvumas [11]. Elektros poreikiai šildymo sistemos veikimui îvertinami nustačius $0,09 \mathrm{MWh} / \mathrm{m}^{2}$, o karšto vandens sistemai $0,05 \mathrm{MWh} / \mathrm{m}^{2}$ pirminès energijos.

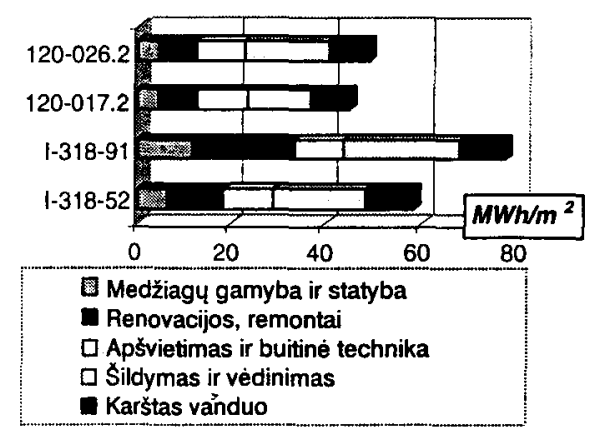

4 pav. Pirminès energijos bendrosios sąnaudos daugiabučiu pastatu gyvavimo cikle

Fig 4. Primary energy total demands for building life cycle of dwelling houses

Vidutiniai elektros poreikiai patalpu apšvietimui vertinami $3 \mathrm{~W} / \mathrm{m}^{2}$, o buitinei technikai - apie $1,5 \mathrm{~W} / \mathrm{m}^{2}$, o perskaičiavus $\mathfrak{i}$ pirminę energiją abiem pastatams poreikiai apšvietimui ịvertinami $6,83 \mathrm{MWh} / \mathrm{m}^{2}$, o buitinei technikai $-3,75 \mathrm{MWh} / \mathrm{m}^{2}$. Einamojo remonto energijos poreikiams ìvertinti šiame analizès lygyje galima pasinaudoti tik praktiniu rodikliu, kad einamajam remontui kasmet sunaudojama apie $1 \%$ pastato vertès. Šis ir kiti procentais išreiškiami santykiniai rodikliai ateityje turètų būti tikslinami, nes ne visuomet didesnę statybos vertę atitinka proporcingos išlaidos remontams ar renovacijai.

Vadinasi, per nagrinèjamų pastatu gyvavimo ciklą energijos sąnaudos einamajam remontui kinta nuo 3,36 iki 8,92 $\mathrm{MWh} / \mathrm{m}^{2}$. Pastato gyvavimo daugiau kaip 70-75 mety trukmès cikle logiška numatyti dvi renovacijas (kapitalinius remontus), kurių abiejų vertė vertinama 1,3\% kasmetiniy atskaitymy nuo pastato vertès. Šiuo atveju nagrinejamiems pastatams tai sudarytu nuo 4,36 iki 11,6 MWh/m². Kitas būdas paremtas pirminès energijos poreikiu apskaičiavimu atskiriems pastato ir inžineriniu sistemų elementams bei ju gyvavimo trukme kaip kartotiniu dydžiu pastato gyvavimo cikle. Stogo vandens ir šilumos izoliacijos gyvavimo trukmè vertinama 15 metu, sienı šilumos 
izoliacijos ir langu - 25 metais, inžinerinių sistemụ reguliavimo jranga - 10 metų, šilumos šaltiniai - 20 metu, o vamzdynai su radiatoriais - iki 30 metų.

Sujungus pastato gyvavimo ciklo etapus $\mathfrak{i}$ dar didesnes grupes, galima gauti pirminès energijos poreikių pasiskirstymą tarp pastato konstrukcinès dalies bei mikroklimato sistemų (žr. 5.)

a)

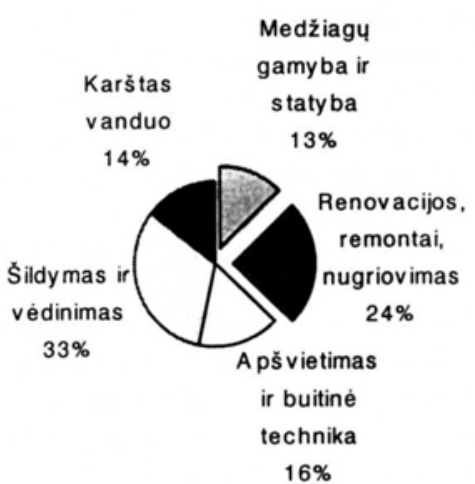

b)

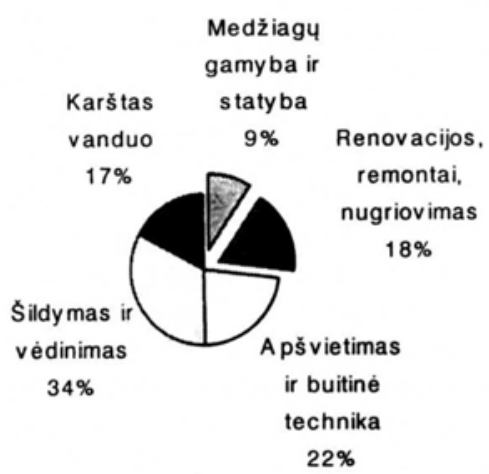

5 pav. Pirminés energijos bendrujų sąnaudu pasiskirstymas daugiabučiu pastaty gyvavimo cikle: a) stambiaplokščiams pastatams; b) plytiniams pastatams

Fig 5. Distribution of primary energy demands of building life cycle of dwelling houses: a) concrete panel buildings b) brick houses

Taigi nagrinejjamuose projektuose, kaip ir kituose daugiabučiuose pastatuose, beveik $3 / 4$ pirminès energijos poreikių sudaro mikroklimato, komforto sistemy poreikiai, o šildymas ir vèdinimas - 1/3 pastato pirminès energijos poreikių. Šių sistemų techninis, pirmiausia termodinaminis tobulumas yra pagrindinis strateginis uždavinys mažinant pirminès energijos poreikius gyvenamuosiuose pastatuose. Kita vertus, šių sistemy̨ nominaliajai galiai ir pastato išorinių atitvaru šiluminèms charakteristikoms taip pat reikia optimalaus suderinimo pastato gyvavimo ciklo pirminès energijos poreikių požiūriu.

\section{Išvados}

1. Pirminès energijos poreikis nagrinejjamy tipinių daugiabučių pastatụ medžiagų gamybai ir statybai, atsižvelgiant $\mathfrak{i}$ projektinius sprendimus ir statybos darbų technologijos ypatybes, skiriasi. Stambiaplokščiam penkiaaukščiam pastatui jis lygus $4,42 \mathrm{MWh} / \mathrm{m}^{2}$, devyniaaukščiam - 4,36 $\mathrm{MWh} / \mathrm{m}^{2}$, atitinkamai pagal aukštingumą mūriniams - 6,35 $\mathrm{MWh} / \mathrm{m}^{2}$ ir 11,59 MWh/m².

2. Pasikartojantys pirminès energijos poreikiai (pastato eksploatacijai ir einamajam remontui) stambiaplokščiam penkiaaukščiam pastatui lygūs $35,45 \mathrm{MWh} / \mathrm{m}^{2}$, devyniaaukščiam - 39,77 MWh/m², atitinkamai pagal aukštingumą müriniams $44,83 \mathrm{MWh} / \mathrm{m}^{2}$ ir $52,54 \mathrm{MWh} / \mathrm{m}^{2}$. Šildymui ir vėdinimui reikia apie $40 \%$ pirminès energijos, likusioji poreikių dalis tenka karšto vandens ruošimui, apšvietimui, buitinei technikai ir einamiesiems remontams. Dviem renovacijoms ir nugriovimui pastato gyvavimo cikle tenka nuo $5 \mathrm{iki} 12 \mathrm{MWh} / \mathrm{m}^{2}$.

3. Esamuose daugiabučiuose pastatuose beveik $3 / 4$ pirminès energijos poreikiy sudaro mikroklimato, komforto sistemy poreikiai, o šildymui ir védinimui reikia 1/3 pastato gyvavimo ciklo pirminès energijos poreikių. Šių sistemų techninis, pirmiausia termodinaminis tobulumas yra pagrindinis strateginis uždavinys mažinant pirminès energijos poreikius gyvenamuosiuose pastatuose, o ju nominaliajai galiai ir pastato išoriniu atitvaru šiluminėms charakteristikoms reikia optimalaus pastato gyvavimo ciklo pirminès energijos poreikių suderinimo.

4. Tokiems pastato gyvavimo ciklo etapams, kaip statybos procesas, remontai, renovacijos, reikia atskiro, detalesnio technologiniu procesy termodinaminio įvertinimo, kurio metodinis pagrindas galètų būti siūlomas pastato gyvavimo ciklo termodinaminis modelis.

5. Šiuo metu, ivertinant pagrindiniu konstrukcinių ir izoliacinių medžiagu gamybos bei statybos montavimo procesy energijos poreikius Lietuvoje, patikimais galima laikyti antrojo lygmens technologinio proceso apimties duomenis. Ketvirtojo lygmens energijos poreikių duomenims nustatyti papildomai reikia kitų šalies pramonès šaku energijos poreikių analizès. Statybos pramonès plètrai prognozuoti reikia šios šakos technologiniu procesł monitoringo pagal skirtingus jụ apimties lygmenis. 
6. Pastato gyvavimo ciklo vertès tyrimams turi būti sukurta reglamentuota valstybinè sistema, verčianti proceso dalyvius stebèti ir registruoti pastato gyvavimo ciklo tiek fizinius, tiek ekonominius duomenis, išvestinius rodiklius. Savo veikloje šiais deriniais galèty naudotis pastato gyvavimo ciklo dalyviai (mokslininkai, projektuotojai, statytojai, savininkai).

\section{Literatūra}

1. Э. К. Завадскас. Системотехническая оценка технологических решений строительного производства. Ленинград: Стройздат, 1991. 256 с.

2. V. Martinaitis. Lietuvos pastaty šiluminio renovavimo mikroekonominis tikslingumas // Aplinkos inžinerija, Nr. 1(3), V.: Technika, 1995, p. 4-19.

3. Lietuvos energetika' 97 / Lietuvos ūkio ministerija, Lietuvos energetikos institutas, 1998.

4. V. Martinaitis. Pastato tarnavimo ciklo termodinaminio vertinimo veiksniai // Statyba, 3(7), V.:Technika, 1996, p. 75-84.

5. Я. Шаргут, Р. Петела. Эксергия / Перевод с польского. Под ред. В.М. Бродянского. Москва: Энергия, 1968. 279 с.

6. Эксергетические расчеты технических систем: Справ. пособие / Под ред. А.А. Долинского, В.М. Бродянского. АН УССР. Инст. технической теплофизики. Киев: Наук. думка, 1991. 360 с.

7. V. Martinaitis. Pastato gyvavimo ciklo energinio ir ekologinio ịvertinimo modelis // Aplinkos inžinerija, VI t., Nr. 2, V.: Technika, 1998, p. 64-71.

8. K. Čiuprinskas, V. Martinaitis. Pirminès energijos poreikiu statybinems medžiagoms nustatymo ypatumai // Statyba, Nr. 3(11), V.: Technika, 1997, p. 35-43.

9. B.Stein, J.S. Reynolds. Mechanical and electrical equipment for buildings. New York: Wiley cop. 8th ed., 1992. $1627 \mathrm{p}$.

10. V. Martinaitis. Analytic calculation of degree-days for the regulated heating season // International Journal of Research Applied to Energy Efficiency in the Built Environment. Energy and Buildings 28, Elsevier Sience S.A., 1998, p. 185-189.

11. V. Martinaitis. Sezoninis šildymo katilo efektyvumas Lietuvos klimato sąlygomis // Lietuvos mokslo darbai. Energetika, 1997, Nr. 4, p. 88-93.

Iteikta 19981203

\section{THE DEMAND FOR EXERGY DURING THE LIFE CYCLE OF DWELLING HOUSES}

\section{Martinaitis}

Summary

The heat demand for heating and ventilation of dwelling houses depends on the climate and thermal characteristics of buildings. Energy is consumed not only in the process of maintenance of a building, but also for constructing it. The aim of current research is to assess the needs of a building life cycle (constructing, maintenance, demolition) expressed in energy units.
In order to determine the energy demand of the building life cycle, lasting from a few decades to a century, the thermodynamic methodology is used. The chosen method is based on a systematic approach, applying analysis through combination of approaches such as thermodynamics exergic approach and method of an economic life cycle. The exergic method describes the energy of different types not only by its quantity, but also by the quality, ie it evaluates different forms of energy and its sources by the same quality criteria.

According to the design data of four main types of blocks of flats, based on splitting the thermodynamic model into special stages and analysing data of the primary energy consumption of material processing, and the stages of it, the comparative primary energy consumption levels are defined for the principal building material production and the construction process.

Primary energy consumption for typical block of flats construction material processing (forming construction goals, planning, research, coordination, designing, management of the construction process, labour force costs, service costs, transportation, use of machinery, energy and fuel consumption) is different as regards the design variations and construction work technology. For the concrete panel five-storey building it amounts to $4,42 \mathrm{kWh} / \mathrm{m}^{2}$, for a ninestorey building $4,36 \mathrm{kWh} / \mathrm{m}^{2}$, for a five-storey brick house $6,35 \mathrm{kWh} / \mathrm{m}^{2}$, and $11,59 \mathrm{kWh} / \mathrm{m}^{2}$ for a nine-storey building.

Regular primary energy consumption needs (maintenance and repairs) for a concrete panel five-storey building are $35,45 \mathrm{kWh} / \mathrm{m}^{2}$, for a nine-storey building $39,77 \mathrm{kWh} / \mathrm{m}^{2}$, for a five-storey brick house $44,83 \mathrm{kWh} / \mathrm{m}^{2}$, and $52,54 \mathrm{kWh} / \mathrm{m}^{2}$ for a nine-storey building. 40 per cent of the consumed energy is used for heating and ventilation, the rest of it is used for hot water preparation, lighting, home appliances and repairs. Two renovations and demolition of a building (manufacture of materials and products for renovation, research, designing, realization of the projects, demolition of the building, regeneration of the territory and the waste, systemating the data, development of a new technology) need within the building life cycle from 5 to $12 \mathrm{kWh} / \mathrm{m}^{2}$ of energy.

In the existing blocks of flats almost three fourths of energy are used for microclimate and comfort systems, whereas heating and conditioning require one third of primary energy used within the building life cycle. The main strategy for diminishing the level of primary energy consumption in dwelling houses is aimed at developing of technical, mostly thermodynamic, features of heating systems and considering nominal power of those systems and the heating characteristics of exterior surfaces, the optimal coordination of building life cycle energy demands.

Vytautas MARTINAITIS. Doctor, Associated Professor. Department of Heating and Ventilation. Vilnius Gediminas Technical University, Sauletekio al. 11, 2040 Vilnius, Lithuania.

Doctor's degree at Belorussian Polytechnical Institute (1982, power engineering and thermoengineering). Since 1989 he has been working at Vilnius Technical University. Research courses: in Belorussia (1982), Spain (1992-1993), Switzerland (1993-1994), the UK (1995). Research interests: optimization of energy consumption in buildings. 